\title{
Lukasz Furman
}

Uniwersytet Rzeszowski

e-mail: lukef@wp.pl

\section{Witold Furman}

Uniwersytet Ekonomiczny w Krakowie

e-mail: witold.furman@uek.krakow.pl

\section{OPTYMALIZACJA PODATKOWA TRANSAKCJI KAPITAŁOWYCH W SPÓŁKACH}

\section{TAX OPTIMIZATION OF CAPITAL TRANSACTIONS IN COMPANIES}

DOI: $10.15611 /$ pn.2017.484.07

JEL Classification: H21

Streszczenie: Przedsiębiorcy zawsze poszukiwali możliwości rozwiązań podatkowych, które przynosiłyby korzyści finansowe. Artykuł omawia problematykę związaną z transakcjami kapitałowymi występującymi w spółkach. Operacje te dotyczą w szczególności połączenia lub podziału spółek, podwyższenia kapitału zakładowego, umorzenia akcji. Wszelkie transakcje kapitałowe udziałowcy lub akcjonariusze spółek chcieliby przeprowadzać przy zminimalizowaniu obciążeń podatkowych. Wiąże się z tym optymalizacja podatkowa, która w sposób legalny przy wykorzystaniu odpowiednich metod pozwala na zmniejszenie płaconych podatków z tytułu przeprowadzonych operacji kapitałowych. Obniżenie płatności podatku bądź jego całkowite wyeliminowanie dotyczy spółek, które często występują jako podatnicy oraz udziałowcy, którzy od otrzymanych dochodów kapitałowych zmuszeni są zapłacić podatek dochodowy. Artykuł zawiera wnioski z przeprowadzonej analizy systemu podatkowego pod kątem rozwiązań optymalizacyjnych.

Słowa kluczowe: kapitał, przedsiębiorstwo, system podatkowy, podatek.

Summary: Entrepreneurs have always been actively looking for tax solutions that would provide positive financial returns. This article discusses issues related to capital transactions occurring in companies. These operations concern, in particular, the merger or division of companies, increase in share capital and redemption of shares. Any equity transactions the shareholders or shareholders of companies would like to carry out while minimizing the tax burden. This involves tax optimization, which lawfully uses appropriate methods to reduce the taxes paid on capital transactions. The reduction of tax payments or the total elimination of taxation applies to companies that often appear to be taxpayers and shareholders who are required to pay income tax on capital gains received. Finally, the article concludes with the analysis of the tax system in terms of optimization solutions.

Keywords: capital, enterprise, tax system, tax. 


\section{Wstęp}

Problematyka kapitałów jest bardzo ważna z punktu widzenia działalności gospodarczej, niezależnie od formy organizacyjnej. Każde przedsiębiorstwo prezentuje odmienne zapotrzebowanie na kapitał. Jest to zależne od realizowanych zadań operacyjnych czy inwestycyjnych. Jeśli jednostka gospodarcza nie posiada wystarczających własnych zasobów majątkowych, zainteresowana jest pozyskaniem obcych środków, a przy tym jak najmniejszym kosztem kapitału. W transakcjach kapitałowych, które dokonywane są w ramach działalności gospodarczej, nieodłączną częścią przeprowadzanych operacji finansowych są obciążenia podatkowe. Przedsiębiorcy od zawsze chcieli płacić jak najmniej podatku z tytułu prowadzonej działalności. Ta sytuacja dotyczy również transakcji kapitałowych w ramach struktur jednostki. Minimalizacja wszelkiego rodzaju danin publicznych jest tematem zawsze aktualnym dla podatników, skłaniającym ich do coraz większego zainteresowania się tą tematyką w celu ochrony wypracowanego przez nich kapitału (dochodu).

Celem niniejszego artykułu jest przegląd rozwiązań podatkowych, które oddziałują na transakcje kapitałowe, i odpowiedź na postawioną hipotezę, która brzmi: w polskim systemie podatkowym możliwa jest optymalizacja podatkowa w ramach transakcji kapitałowych. Wiedza w tym zakresie jest niezbędna przy podejmowaniu decyzji o realizacji tego rodzaju transakcji. W pracy wykorzystano następujące metody badawcze:

- studia literaturowe dotyczące pojęć i przepisów podatkowych odnoszących się do optymalizacji podatkowej w przeprowadzanych transakcjach kapitałowych;

- metodę opisową wykorzystaną przy konkretnych transakcjach kapitałowych przeprowadzanych w obrębie działalności gospodarczej oraz analizę przepisów prawnych.

\section{Pojęcie optymalizacji podatkowej}

Termin „optymalizacja podatkowa” dotyczy wyboru takiego narzędzia podatkowego przez podatnika, które w znaczący sposób przyczyni się do oszczędności podatkowych. Skorzystanie z danego rozwiązania oznacza płacenie możliwie najniższych podatków. Co bardzo ważne - uiszczanie mniejszych podatków powinno płynąć z przepisów materialnego prawa podatkowego. Jeśli podatnik korzysta z rozwiązań podatkowych utożsamianych $\mathrm{z}$ optymalizacją podatkową, to niewątpliwie będzie to zawsze działanie zgodne z prawem. Problematyka optymalizacji podatkowej nie jest rzeczą nową, którą dostrzeżono obecnie. Na przestrzeni lat wyrażało się na jej temat wielu ekonomistów. Z zagranicznych ekonomistów znany jest Frank Romsey, który w badaniach skupiał się na opodatkowaniu towarów podatkami pośrednimi, jak również opodatkowaniu dochodu [Romsey 1927]. Pod koniec XX w. problematyka optymalizacji podatkowej dostrzegana była w pracach C. Heady'ego, który w swym kręgu zainteresowań stawiał optymalne opodatkowanie [Heady 1993]. 
Pamiętać należy, że optymalizacja podatkowa wynika z narzuconych przepisów prawa podatkowego w danym państwie. Rozwiązania mogą być odmienne, natomiast będą miały wspólny cel, zmierzający do ograniczenia ciężaru podatkowego bądź całkowitego jego wyeliminowania. W polskiej rzeczywistości gospodarczej również do problemu optymalizacji podatkowej odniósł się sąd administracyjny, twierdząc w jednym z wyroków, że „, żadnej normy prawnej nie można wyprowadzić zasady nakładającej na podatnika obowiązek działania do powstania zobowiązania podatkowego w najwyższej możliwej wysokości. Jeżeli obowiązujący porządek prawny stwarza podatnikowi możliwość wyboru kilku legalnych konstrukcji do osiągnięcia zamierzonego celu gospodarczego, z których każda będzie miała inny wymiar podatkowy, to wybór najkorzystniejszego podatkowo rozwiązania nie może być traktowany jako obejście prawa" [Wyrok SA 2003].

Jednostki gospodarcze, które wnoszą podatki do budżetu centralnego i budżetów samorządu terytorialnego, nie podlegają żadnym zasadom, które pociągałyby za sobą zwiększone obciążenia (nadmierne) z punktu widzenia Skarbu Państwa. Taki pogląd pojawił się w wyroku Naczelnego Sądu Administracyjnego z 31.01.2002 r.; jego tezy doprowadzają do następujących twierdzeń:

- „z istoty prawa podatkowego można wyprowadzić zasadniczą normę nakazującą zapłatę podatku w sytuacji spełnienia warunków powodujących powstanie zobowiązania podatkowego. Nie istnieje natomiast generalna zasada nakładająca na podatnika obowiązek działania dla powstania zobowiązania w wysokości największej z możliwych;

- istotą działalności gospodarczej jest maksymalizacja zysku, a nie maksymalizacja zobowiązań podatkowych" [Wyrok NSA 2002].

Podejście do dzisiejszej optymalizacji podatkowej polega przede wszystkim na planowaniu i wdrożeniu działań zmierzających do eliminacji bądź zmniejszania ciężaru podatkowego. Musi się to odbywać przy wykorzystaniu dozwolonych prawem norm. Przedmiotem takiej optymalizacji jest zgodność działania podatnika z obowiązującym prawem oraz związanie organów podatkowych skutkami takich czynności. Dotyczy to podatników prowadzących działalność gospodarczą, tj. osób prawnych i osób fizycznych [Mazur 2012].

W normach prawnych nie znajdziemy definicji optymalizacji podatkowej. Pojęcie to jest często używane w języku zawodowym prawników i doradców podatkowych i uznawane za sposób na zmniejszenie ciężaru podatkowego. W Stowniku wyrazów obcych znajdujemy podstawowy termin: „optymalizacja”, który oznacza poszukiwanie przy użyciu metod matematycznych optymalnego (najlepszego i najkorzystniejszego), ze względu na wybrane kryterium, rozwiązania danego zagadnienia gospodarczego, przy uwzględnieniu danych ograniczeń.

$\mathrm{Na}$ łamach polskiej literatury do optymalizacji podatkowej znajdujemy niżej wymienione odniesienia:

1. Chróścicki i inni autorzy [2012] piszą o optymalizacji podatkowej, iż jest to korzystanie $\mathrm{z}$ dostępnych prawem narzędzi w celu zmniejszenia ciężaru podatkowego. 
2. Wyciślok [2013] mówi, że jest to inteligencja podatkowa, ponieważ dotyczy inteligentnego stosowania przepisów w celu obniżenia zobowiązań podatkowych.

3. Ladziński [2010] wskazuje, że dzięki optymalizacji podatkowej przedsiębiorcy mogą uzyskać lepsze wyniki finansowe, co w konsekwencji przyczynia się do powiększenia aktywów przedsiębiorstwa.

4. Gruziel [2009] wypowiada się o instrumentach optymalizacji podatkowej umożliwiających kształtowanie zobowiązań podatkowych, wśród których można wyróżnić:

a) instrumenty o działaniu fundamentalnym, np. zmiana formy prawnej, przeniesienie siedziby do kraju stosującego łagodniejszą politykę podatkową;

b) instrumenty kompleksowe, obejmujące wiele czynności formalnych, np. zmiana roku podatkowego z kalendarzowego na inny okres kolejnych 12 miesięcy;

c) bieżące instrumenty optymalizacji, m.in. wybór metody i sposobu amortyzacji.

5. Walicka [2012], mówiąc o optymalizacji podatkowej, ma na myśli jedynie działania przedsiębiorstwa, które są legalne, prowadzone w ramach istniejących przepisów prawnych, obejmujących zarówno podatki, jak również inne zobowiązania publicznoprawne. Jest to zatem świadome i inteligentne stosowanie prawa podatkowego w celu obniżenia obciążeń podatkowych. Optymalizacja podatkowa jest niezbędna dla polskich przedsiębiorstw, gdyż niejasny i skomplikowany system podatkowy oraz liczba i wysokość płaconych podatków są od wielu lat wymieniane jako główne bariery rozwoju przedsiębiorczości w Polsce.

6. Kata [2015] stwierdza, że efektywne stosowanie optymalizacji podatkowej wymaga od przedsiębiorcy wiedzy na temat istnienia określonych preferencji występujących w systemie podatkowym oraz możliwości ich zastosowania lub korzystania z wiedzy doświadczonego doradcy podatkowego.

Wdrożenie metod optymalizacji podatkowej w danym przedsiębiorstwie powinno się rozpocząć od analizy obowiązujących przepisów podatkowych zarówno w obrębie podatków bezpośrednich, jak podatków pośrednich. Ponadto koniecznie trzeba zwrócić uwagę na orzecznictwo wyrażone w decyzjach podatkowych, interpretacjach podatkowych oraz orzeczeniach sądowo-administracyjnych. Głównym punktem podjętych działań powinno być optymalne przygotowanie planu działania, który będzie korzystny finansowo z punktu widzenia prowadzonego przedsiębiorstwa. Plan działań optymalizacyjnych powinien uwzględniać oszczędności finansowe i być wprowadzany wtedy, gdy gospodarka jest w kryzysie i są zatory płatnicze [Przychocka 2012].

Europejski Trybunał Sprawiedliwości w orzecznictwie wskazuje, że planowanie i prowadzenie swoich spraw podatkowych przez podatnika w taki sposób, aby uzyskał on określone korzyści podatkowe, nie stanowi nadużycia prawa. Podmiot płacący podatki nie ma obowiązku prowadzenia działalności w taki sposób, aby powodowała ona maksymalizację dochodów państwa. Wyrok ETS podkreśla i uwidacznia legalność funkcjonowania optymalizacji podatkowej w ramach całej Unii Europejskiej. Do działań związanych z optymalizacją podatkową zaliczyć można: 
- $\quad$ optymalizację w zakresie podatku od czynności cywilnoprawnych;

- $\quad$ optymalizację w zakresie podatku od spadków i darowizn;

- optymalizację podatkową zysków z handlu międzynarodowego, handlu internetowego;

- e-commerce oraz usługi świadczone zdalnie;

- $\quad$ optymalizację podatkową zysku operacyjnego poprzez alokację części źródeł kosztów poza granicami danego kraju;

- $\quad$ optymalizację podatkową przychodów z wartości niematerialnych i prawnych;

- $\quad$ inne optymalizacje obciążeń podatkowych [Raczkowski i in. 2012].

Podstawowe formy optymalizacji podatkowej dotyczą zarządzania elementami kosztów podatkowych. W dalszej kolejności odnoszą się do składników aktywów i pasywów przedsiębiorstw. Jeśli mowa o źródłach pochodzenia majątku, na który składają się kapitały własne oraz obce, to optymalizacja może również odnosić się do działań z zakresu transakcji kapitałowych.

\section{Wykorzystanie podatkowych technik optymalizacyjnych do zmniejszania ciężaru podatkowego w transakcjach kapitałowych}

Rozpatrując transakcje kapitałowe, nie sposób pominąć określenia, czym właściwie one są. Przede wszystkim istotą transakcji kapitałowych jest ścisły związek z kapitałem. Dokonuje się ich na rynku finansowym z użyciem właściwych instrumentów. Nie jest to jedyne miejsce, gdzie odbywają się tego typu operacje. Mają one związek z funkcjonowaniem spółek kapitałowych i spółek osobowych.

Połączenie lub podział spółek, podwyższenie kapitału zakładowego, pożyczka od udziałowca, dopłaty w spółce z ograniczoną odpowiedzialnością - to najczęściej spotykane transakcje kapitałowe. Decyzja o ich przeprowadzeniu powinna być jednak poprzedzona nie tylko szczegółową analizą skutków ekonomiczno-finansowych, lecz także analizą i właściwym planowaniem podatkowym. Takie zorganizowanie sprawy pozwoli na prawnie dopuszczalne zminimalizowanie obciążeń podatkowych związanych z takimi transakcjami.

\subsection{Połączenie spółek kapitałowych}

Wśród transakcji kapitałowych dotyczących spółek dość często pojawia się łączenie spółek. Procedura oraz zasady łączenia się spółek znalazły swe uregulowane w Kodeksie spółek handlowych. Operacja łączenia może znaleźć odzwierciedlenie w trybie:

- łączenia przez przejęcie, polegające na przeniesieniu całego majątku spółki przejmowanej na spółkę przejmującą w zamian za udziały lub akcje, które spółka przejmująca wydaje wspólnikom spółki przejmowanej;

- zawiązania nowej spółki kapitałowej oraz następnie przejścia majątku wszystkich łączących się spółek za udziały lub akcje nowej spółki. 
Wybór danego wariantu połączenia spółek implikuje określone skutki podatkowe. Dotyczy to przede wszystkim następstw czynności połączenia spółek. Przepisy ordynacji podatkowej odnoszą się do sukcesji podatkowej, która wyraża się w tym, iż osoba prawna zawiązana (powstała) w wyniku łączenia się osób prawnych, osobowych spółek handlowych, osobowych i kapitałowych spółek handlowych, wstępuje we wszystkie przewidziane $\mathrm{w}$ przepisach prawa podatkowego prawa i obowiązki każdej z łączących się spółek. Reguła ta ma odniesienie do podatnika będącego osobą prawną, który łączy się przez przejęcie innej osoby prawnej (osób prawnych), osobowej spółki handlowej (osobowych spółek handlowych).

Po zakończeniu połączenia, co następuje z chwilą wpisania do rejestru przedsiębiorców czynności prawnej połączenia spółek, przejęte spółki wykreślone są z Krajowego Rejestru Sądowego. Na spółce przejmującej lub nowo powstałej ciążą liczne obowiązki, m.in.:

- złożenie do organu podatkowego wniosków o wykreślenie spółki przejętej jako podatnika VAT oraz dokonanie rozliczenia VAT za ostatni okres rozliczeniowy, kiedy funkcjonowała spółka przejęta, oraz rozliczenia rocznego podatku dochodowego za ostatni rok podatkowy spółki przejętej;

- przejęcie funkcji płatnika przez spółkę przejmującą.

W ramach sukcesji podatkowej spółka przejmująca ma prawo do uzyskania zwrotu kwoty podatku wykazanego przez spółkę przejmowaną za ostatni okres rozliczeniowy przed przejęciem. Dodatkowo przysługuje jej również prawo do obniżenia podatku należnego o kwotę podatku naliczonego, wynikające $\mathrm{z}$ faktur zakupowych wystawionych przed dniem połączenia na spółkę przejmowaną.

Przy omawianych przekształceniach istnieje pewne ograniczenie przy sukcesji uniwersalnej. Na podstawie art. 7 ust. 4 ustawy o podatku dochodowym od osób prawnych, przy ustalaniu straty nie uwzględnia się straty przedsiębiorców przekształcanych, łączonych, przejmowanych lub dzielonych, z wyjątkiem przekształconych spółek kapitałowych w inne spółki kapitałowe. Sytuacja ta oznacza, iż jeśli spółka przejmująca będzie kontynuować działalność na podstawie połączonych majątków przejmowanych spółek, to w rocznym rozliczeniu może odliczyć część swojej straty. Nie jest natomiast możliwe wspólne rozliczanie strat spółek przejmowanych ze spółką przejmującą.

Takie ukształtowanie rozwiązań prawnych eliminuje więc w praktyce skorzystanie z pewnej optymalizacji (łączenia dochodów i strat w jednym rozliczeniu) poprzez połączenie się spółki o dobrych wynikach finansowych ze spółką o ujemnych wynikach finansowych. Wykreślenie spółki przejmowanej z rejestru KRS (osiągającej straty) nie jest również podstawą do rozliczenia straty $z$ dochodem wygenerowanym w latach następnych przez spółkę przejmującą.

Również połączenie spółek dokonywane poprzez zawiązanie nowej spółki powoduje, że straty łączących się spółek nie będą mogły być uwzględniane przy ustalaniu podstawy opodatkowania spółki powstałej w wyniku takiego połączenia. Niewątpliwie brak możliwości uwzględniania w rozliczeniu rocznym strat spółek 
przejmowanych jest czynnikiem determinującym możliwość zastosowania optymalizacji podatkowej.

Proces łączenia spółek powoduje również inne konsekwencje podatkowe. Zgodnie $\mathrm{z}$ art. 10. ust. 2 pkt 1 ustawy o podatku dochodowym od osób prawnych dla spółki przejmującej lub nowo zawiązanej, przy połączeniu lub podziale spółek kapitałowych, nie stanowi dochodu z tytułu udziału w zyskach osób prawnych nadwyżka wartości otrzymanego przez spółkę przejmującą lub nowo zawiązaną majątku spółki przejmowanej lub dzielonej ponad wartość nominalną udziałów (akcji) przyznanych udziałowcom (akcjonariuszom) spółki przejmowanej lub dzielonej. W przypadku spółki przejmującej, która posiada udział w kapitale zakładowym spółki przejmowanej lub dzielonej w wysokości mniejszej niż 10\%, dochód stanowi nadwyżka wartości przejętego majątku odpowiadająca procentowemu udziałowi w kapitale zakładowym spółki przejmowanej lub dzielonej nad kosztami uzyskania przychodu obliczonymi zgodnie $\mathrm{z}$ art. 15 ust. $1 \mathrm{k}$ lub art. 16 ust. 1 pkt 8 . Dochód ten określa się na dzień wykreślenia spółki przejmowanej lub dzielonej z rejestru albo na dzień wydzielenia.

Czerpiąc wiedzę z tych regulacji, wywodzić można, że brak powiązań kapitałowych bądź przejęcie spółki, w której udział w kapitale jest wyższy niż 10\%, wprowadza dla spółki przejmującej rozwiązanie oznaczające brak opodatkowania dochodu z tytułu udziału w zyskach osób prawnych w związku z procesem połączenia lub podziału spółek.

Przewidziane przez ustawodawcę zasady nie będą mieć jednak zastosowania, jesli przyczyną transakcji przejęcia jest uniknięcie lub uchylenie się od opodatkowania. W tym przypadku organ podatkowy będzie musiał wskazać w ramach kontroli podatkowej brak przesłanek ekonomicznych uzasadniających połączenie spółek.

Ustawa o podatku dochodowym od osób prawnych dla podmiotu, który posiada status spółki przejmującej, wprowadza również uregulowania odnoszące się do zasad amortyzacji stosowanych dla środków trwałych oraz wartości niematerialnych i prawnych przejętych w wyniku procesu połączenia spółek. Konieczna jest kontynuacja tych samych stawek amortyzacji, które dotychczas były stosowane przez spółkę przejętą. Spółka przejmująca może zmienić stawki amortyzacyjne, ale według ściśle określonych zasad wskazanych w ustawie o podatku dochodowym od osób prawnych. Najczęściej dotyczy to sytuacji, kiedy warunki używania środków trwałych zmieniają się na złe, pogorszone lub lepsze od przeciętnych.

Analiza dotychczasowych uregulowań pozwala stwierdzić, iż proces połączenia spółek nie jest więc dogodny do przejęcia majątku trwałego, ustalenia jego nowej wartości po przeszacowaniu i rozpoczęcia efektywniejszej amortyzacji pozwalającej zwiększyć koszty podatkowe. Planowanie wydatków związanych z połączeniem jest więc bardzo ważne, aby obciążenia podatkowe po stronie spółki przejmującej były jak najmniejsze.

W aspekcie połączenia spółek nie należy zapominać o skutkach podatkowych, które zachodzą po stronie udziałowców/akcjonariuszy spółek przejmowanych. 
Wspólnik wspomnianej spółki w zamian za udziały/akcje spółki przejmowanej otrzymuje udziały/akcje spółki przejmującej. Zwykle są one przeliczane według określonego sposobu. Nie zawsze możliwe jest dopasowanie wartości akcji/udziałów, przez co ustawodawca przewidział mechanizm dopłat do udziałów, co ma służyć niwelowaniu powstałych w ten sposób różnic. Dopłata w gotówce dla udziałowca/ akcjonariusza do wydanych mu udziałów/akcji stanowi podlegający opodatkowaniu dochód z udziału w zyskach osób prawnych.

W przypadku gdy transakcja zamiany udziałów/akcji spółki przejmowanej na udziały/akcji spółki przejmującej zachodzi w związku z czynnością prawną polegającą na połączeniu spółek, wówczas sytuacja ta jest neutralna podatkowo. Ważne jest również ekonomiczne uzasadnienie połączenia spółek.

\subsection{Podwyższenie kapitału zakładowego}

Wśród transakcji kapitałowych realizowanych w spółkach na uwagę również zasługuje czynność dokapitalizowania. Może się to odbywać poprzez podwyższenie wartości nominalnej zarejestrowanych udziałów bądź akcji lub też jako zapłata za nowo ustanowione udziały lub akcje. Tego typu operacje mogą również rodzić skutki podatkowe. Dla wspólnika lub akcjonariusza skutki podatkowe wystąpią w chwili zbycia posiadanych udziałów lub akcji. Podwyższenie kapitału poprzez objęcie udziałów lub akcji może również nastąpić w zamian za:

- wkład niepieniężny pod postacią przedsiębiorstwa lub zorganizowanej części przedsiębiorstwa, którą stanowi organizacyjnie i finansowo wyodrębniony w istniejącym przedsiębiorstwie zespół składników materialnych i niematerialnych, w tym zobowiązania, przeznaczonych do realizacji określonych zadań gospodarczych, który zarazem mógłby stanowić niezależne przedsiębiorstwo samodzielnie realizujące te zadania;

- wkład gotówkowy.

W chwili podwyższenia kapitału w oparciu o jeden z dwóch powyżej opisanych wariantów transakcja nie wywoła skutków podatkowych w podatkach dochodowych. Opodatkowanie transakcji wystąpi dopiero w momencie odpłatnego zbycia posiadanych udziałów bądź akcji.

W przypadku gdy udziały/akcje obejmowane są za wkład niepieniężny w innej postaci niż przedsiębiorstwo lub zorganizowana jego część, to na podstawie art. 12 ust. 1 pkt $7 \mathrm{w}$ powiązaniu $\mathrm{z}$ art. 12 ust. $1 \mathrm{~b}$ ustawy o podatku dochodowym od osób prawnych na dzień wpisu do rejestru podwyższenia kapitału zakładowego powstaje przychód podatkowy w wysokości nominalnej wartości udziałów/akcji w spółce kapitałowej, które zostały objęte w zamian za wkład w innej postaci niż przedsiębiorstwo lub zorganizowana część przedsiębiorstwa.

Powstały przychód można obniżyć o koszt uzyskania przychodów. Dla takiej transakcji ustalany jest on w sposób zależny od rodzaju wnoszonego wkładu niepieniężnego. Może być brana pod uwagę wartość początkowa przedmiotu wkładu, 
zaktualizowana zgodnie z odrębnymi przepisami, pomniejszona o dokonaną przed wniesieniem tego wkładu sumę odpisów amortyzacyjnych (jeżeli przedmiotem wkładu niepieniężnego są środki trwałe lub wartości niematerialne i prawne) faktycznie poniesionych, niezaliczonych do kosztów uzyskania przychodów.

Rodzaj wnoszonego wkładu do spółki ma również znaczenie w aspekcie uregulowań ustawy o podatku od towarów i usług. Chodzi przede wszystkim o nieobjęcie opodatkowaniem VAT transakcji zbycia przedsiębiorstwa lub zorganizowanej części przedsiębiorstwa, która może samodzielnie wykonywać działalność gospodarczą. Zatem wniesienie przedsiębiorstwa lub zorganizowanej jego części w postaci aportu do spółki pozostanie poza opodatkowaniem podatkiem VAT.

Ważną sprawą w aspekcie transakcji kapitałowych jest operacja gospodarcza polegająca na podwyższeniu kapitału zakładowego, która rodzi również obowiązek podatkowy na płaszczyźnie podatku od czynności cywilnoprawnych. Zobowiązanie podatkowe powstanie z chwilą podjęcia uchwały o podwyższeniu kapitału zakładowego spółki z o.o. Podstawę opodatkowania stanowi wartość, o którą podwyższono kapitał zakładowy. Od podstawy opodatkowania można odliczyć np. kwotę wynagrodzenia pobraną przez notariusza za sporządzenie aktu notarialnego zmiany umowy spółki, jeżeli powoduje ona podwyższenie kapitału zakładowego, a także opłatę sądową związaną ze zmianą wpisu w rejestrze przedsiębiorców dotyczącą zmiany kapitału zakładowego.

Warto wspomnieć, że nie podlegają podatkowi od czynności cywilnoprawnych umowy spółki i ich zmiany związane z wniesieniem do spółki kapitałowej, w zamian za jej udziały lub akcje; przedsiębiorstwa spółki kapitałowej lub jego zorganizowanej części udziałów lub akcji innej spółki kapitałowej dających w niej większość głosów albo kolejnych udziałów lub akcji, w przypadku gdy spółka, do której są wnoszone te udziały lub akcje, posiada już większość głosów.

Podwyższenie kapitału zakładowego wymienionymi sposobami, jak widać, obciążone jest różnego rodzaju obowiązkami podatkowymi. Można oczywiście w sposób legalny uniknąć opodatkowania przy podnoszeniu kapitału własnego, ale musi być to dokładnie zaplanowane pod względem skutków podatkowych.

\subsection{Umorzenie akcji}

Operacją gospodarczą o charakterze typowo kapitałowym, odnoszącym się do kapitałów własnych, jest umorzenie akcji czy też zakup akcji w celu umorzenia. W spółkach akcyjnych umorzenie akcji związane jest jednocześnie z obniżeniem kapitału zakładowego spółki. W spółkach z ograniczoną odpowiedzialnością istnieje inna sytuacja: umorzenie udziału z czystego zysku nie wymaga obniżenia kapitału zakładowego. Dochód uzyskany z umorzenia udziałów/akcji, jak i dochód z odpłatnego zbycia udziałów na rzecz spółki w celu umorzenia został przez ustawodawcę uznany za dochód z udziału w zyskach osób prawnych. W ustawie o podatku dochodowym od osób prawnych znajdziemy również pewien wyjątek, gdy umarzane udziały/akcje 
zostały objęte w zamian za przedsiębiorstwo lub zorganizowaną część przedsiębiorstwa. Dochód z umorzenia ustala się jako różnicę pomiędzy przychodem z tytułu zbycia przez akcjonariusza jego akcji a kosztem poniesionym uprzednio na ich objęcie lub nabycie. Osoba otrzymująca wynagrodzenie z tytułu umorzenia udziałów nie zapłaci podatku, jeśli nie wystąpi dochód do opodatkowania. Podatek również nie będzie należny w sytuacji, gdy koszty poniesione pierwotnie na nabycie lub objęcie umarzanych udziałów/akcji przewyższą wysokość wynagrodzenia uzyskanego tytułem umorzenia udziałów/akcji.

Ważną regulacją zapisaną $\mathrm{w}$ art. 22 ust. 4 ustawy o podatku dochodowym od osób prawnych jest zwolnienie dochodów z zysków osób prawnych (do tego dochodu zalicza się również dochód $\mathrm{z}$ umorzenia udziałów). Wspólnicy spółki z tytułu umorzonych udziałów nie zawsze będą musieli zapłacić podatek. Istnieje kilka sytuacji, gdy ustawa zwalnia z tego obowiązku:

- wypłacającym dywidendę oraz inne przychody z tytułu udziału w zyskach osób prawnych jest spółka będąca podatnikiem podatku dochodowego, mająca siedzibę lub zarząd na terytorium Rzeczypospolitej Polskiej;

- uzyskującym dochody (przychody) z dywidend oraz inne przychody z tytułu udziału w zyskach osób prawnych jest spółka podlegająca w Rzeczypospolitej Polskiej lub w innym niż Rzeczpospolita Polska państwie członkowskim Unii Europejskiej, lub w innym państwie należącym do Europejskiego Obszaru Gospodarczego, opodatkowaniu podatkiem dochodowym od całości swoich dochodów, bez względu na miejsce ich osiągania;

- spółka uzyskująca przychód posiada bezpośrednio nie mniej niż 10\% udziałów (akcji) w kapitale spółki wypłacającej zysk;

- spółka uzyskująca przychód nie korzysta ze zwolnienia z opodatkowania podatkiem dochodowym od całości swoich dochodów, bez względu na źródło ich osiągania.

Zwolnienie ma zastosowanie wyłącznie w przypadku, gdy spółka uzyskująca przychód posiada określoną liczbę udziałów (akcje) w spółce wypłacającej należność nieprzerwanie przez dwa lata.

\section{Zakończenie}

Transakcje kapitałowe to rozległy i skomplikowany temat. Aby osiągnąć zamierzone cele, spółki muszą dokładnie analizować skutki podatkowe transakcji kapitałowych. Ograniczenia wynikające $\mathrm{z}$ formy niniejszego artykułu pozwoliły zasygnalizować najważniejsze rozwiązania podatkowe. Wskazano przede wszystkim, jak istotne jest odpowiednie planowanie podatkowe, dokonywane w procesie decyzyjnym związanym z przeprowadzeniem tych transakcji, pozwalające w sposób zgodny z literą prawa zminimalizować nie tylko ryzyka podatkowe, lecz także koszty realizacji transakcji. 
Postawiona na wstępie hipoteza została pozytywnie zweryfikowana. W przybliżonych regulacjach podatkowych odnoszących się do transakcji kapitałowych występowały konstrukcje, które pozwalały zmniejszać zobowiązania podatkowe zarówno dla udziałowców/akcjonariuszy, jak i spółek. Nie była to zbyt znacząca liczba, jednakże dobrze przygotowany plan działania pod względem transakcji kapitałowych pozwalał na oszczędności podatkowe. Wnioskować należy, iż istniejące przepisy powinny ewoluować w przyszłości w celu ich uproszczenia.

\section{Literatura}

Chróścicki P. i inni, 2012, Optymalizacja podatkowa, Wolters Kluwer, Warszawa.

Dymek M., Błaszczak E., 2004, Optymalizacja obciązeń podatkowych w zakresie podatku dochodowego od osób prawnych - wybrane aspekty, Monitor Podatkowy, nr 9.

Felis P., Jamroży M., Szlęzak-Matusewicz J., 2010, Podatki i składki w działalności przedsiębiorców, Difin, Warszawa.

Gruziel K., Istota i założenia optymalizacji podatkowej - wybrane aspekty, Zeszyty Naukowe SGGW, Ekonomika i Organizacja Gospodarki Żywnościowej, nr 77, s. 178-179.

Heady C., 1993, Optimal Taxation as a Guide to Tax Policy, A Survey Fiscal Studies, vol. 14, no. 1.

Kata R., 2015, Decyzje przedsiębiorców indywidualnych w zakresie optymalizacji podatkowej, Zeszyty Naukowe Szkoły Głównej Gospodarstwa Wiejskiego, Ekonomika i Organizacja Gospodarki Żywnościowej, nr 112, s. 48.

Ladziński A., 2008, Prawne granice optymalizacji podatkowej, Przegląd Podatkowy, nr 6, s. 19.

Mazur Ł., 2012, Optymalizacja podatkowa, Wydawnictwo Wolters Kluwer,

Romsey F.P., 1927, A Contribution to the Theory of Taxation, The Economic Journal, vol. 37, Issue 146 (March 1927), s. 47-61,

Przychocka I., 2012, Kondycja finansowa firmy przez pryzmat analizy finansowej, Wydawnictwo SIG, MA SPJ, Warszawa, s. 50.

Raczkowski K., Krukowski A., 2010, Optymalizacja podatkowa w teorii i praktyce zarządzania wiedza bezpieczeństwa ekonomicznego, Monitor Prawa Celnego i Podatkowego, nr 8, s. 3.

Slownik wyrazów obcych, PWN, Warszawa, http:/sjp.pwn.pl/slowniki/słownik-wyrazów-obcych.html (30.05.2017).

Ustawa z 26 lipca 1991 r. o podatku dochodowym od osób fizycznych, t.j. Dz.U. 2016, poz. 2032.

Ustawa z 15 lutego 1992 r. o podatku dochodowym od osób prawnych, t.j. Dz.U. 2016, poz. 1888.

Ustawa z 9 września 2000 r. o podatku od czynności cywilnoprawnych, t.j. z 2016, poz. 223.

Ustawa z 11 marca 2004 r. o podatku od towarów i usług, t.j. Dz.U. 2016, poz. 710.

Walicka M., 2012, Optymalizacja podatkowa działalności matych przedsiębiorstw, Zeszyty Naukowe Uniwersytetu Szczecińskiego, seria: Finanse, Rynki Finansowe, Ubezpieczenia, nr 52, s. 272.

Wyciślok J., 2014, Optymalizacja podatkowa. Legalne zmniejszanie obciązeń podatkowych, C.H Beck, Warszawa.

Wyrok NSA, 2002, Wyrok Naczelnego Sądu Administracyjnego z I S.A./Gd771/01.

Wyrok SA, 2003, Wyrok Sądu Administracyjnego we Wrocławiu, sygn. I SA/Wr 1183/00. 